This is a self-archived version of an original article. This version may differ from the original in pagination and typographic details.

Author(s): Silva, Pedro Gabriel

Title: The relevance of biographic narratives for social workers' professional memory, reflexivity and identity

Year: 2021

Version: Accepted version (Final draft)

Copyright: (C) 2020, SAGE Publications

Rights: CC BY-NC-ND 4.0

Rights url: https://creativecommons.org/licenses/by-nc-nd/4.0/

Please cite the original version:

Silva, P. G. (2021). The relevance of biographic narratives for social workers' professional memory, reflexivity and identity. Qualitative Social Work: Research and Practice, 20(5), 13741392. https://doi.org/10.1177/1473325020967725 


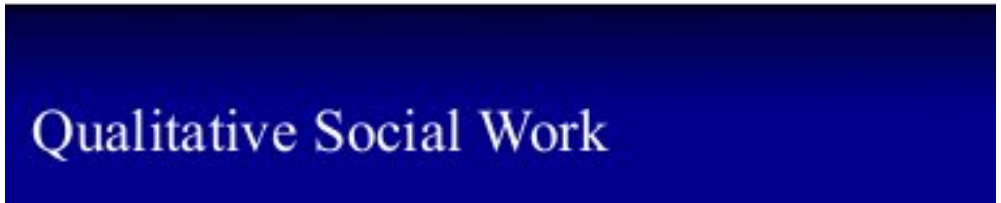

\section{The relevance of biographic narratives for social workers' professional memory, reflexivity and identity}

\begin{tabular}{|r|l|}
\hline Journal: & Qualitative Social Work \\
\hline Manuscript ID & QSW-20-0066.R1 \\
\hline Keywords: & Oral history, Critical reflection, Identity, Biography, Narrative \\
\hline & $\begin{array}{l}\text { The present article is about the use of biographic methods in the } \\
\text { framework of oral history, and its contribution to developing processes of } \\
\text { critical reflection and reflexivity. It is based on a set of oral data } \\
\text { collected from Portuguese social workers who had played an active role } \\
\text { during the revolutionary phase that marked the transition from } \\
\text { dictatorship to democracy in Portugal (following the 25th April 1974 } \\
\text { military coup). The article explores how the use of biographic methods } \\
\text { (integrated within a historical methodological framework), other than } \\
\text { simply producing accounts of past experiences, allowed interviewees to } \\
\text { re-capture, re-interpret and re-signify their own experiences in the light } \\
\text { of changing professional paradigms and socio-political arrangements. It } \\
\text { will demonstrate how resorting to oral history methods can contribute to } \\
\text { produce critical self-reflective accounts, allowing intra-professional } \\
\text { tensions, self-expectations, beliefs and disenchantment, as well as } \\
\text { professional identification and deidentification to surface. Four examples } \\
\text { will be presented that reveal how favouring an approach based on three } \\
\text { interrelated aspects - oral history, biographic methods, narrative analysis } \\
\text { - allows perceiving individual dispositions, its construction and the } \\
\text { influence they have on the subjects' relation with the canons of } \\
\text { professional practice, while showing the ambiguities around professional } \\
\text { representations and identification. }\end{array}$ \\
\hline Abstractions
\end{tabular}

\section{SCHOLARONE Manuscripts}




\title{
The relevance of biographic narratives for social workers' professional memory, reflexivity and identity
}

\author{
Pedro Gabriel Silva* \\ CETRAD-University of Trás-os-Montes and Alto Douro; ISCTE-Lisbon University \\ Institute; Kokkola University Consortium Chydenius - University of Jyvaskyla \\ * University of Tras-os-Montes and Alto Douro \\ Pólo II - Escola de Ciências Humanas e Sociais \\ Quinta de Prados, s/n \\ 5000-801 VILA REAL - PORTUGAL
}

\begin{abstract}
:
The present article is about the use of biographic methods in the framework of oral history, and its contribution to developing processes of critical reflection and reflexivity. It is based on a set of oral data collected from Portuguese social workers who had played an active role during the revolutionary phase that marked the transition from dictatorship to democracy in Portugal (following the $25^{\text {th }}$ April 1974 military coup). The article explores how the use of biographic methods (integrated within a historical methodological framework), other than simply producing accounts of past experiences, allowed interviewees to re-capture, re-interpret and re-signify their own experiences in the light of changing professional paradigms and socio-political arrangements. It will demonstrate how resorting to oral history methods can contribute to produce critical self-reflective accounts, allowing intra-professional tensions, self-expectations, beliefs and disenchantment, as well as professional identification and deidentification to surface.
\end{abstract}


Three examples will be presented that reveal how favouring an approach based on oral history, biographic methods and narrative analysis allows perceiving individual dispositions, its construction and the influence they have on the subjects' relation with the canons of professional practice, while showing the ambiguities around professional representations and identification.

Keywords: oral history, biographic narratives, critical reflection, narrative analysis, identity

\section{Introduction}

The present article revolves around the contribution of oral history and biographic inquiry to collecting social workers' social and professional memory, and, in particular, its ability to induce reflexivity and identity framing. The article will explore the relationship between oral history and biographic methods and narrative analysis, critical reflection, reflexivity and identity (re)framing, based on three examples taken from an ongoing research. The empirical ground is a set of biographic interviews collected from Portuguese social workers who were actively engaged in some of the most progressive programmes, projects and events developed in Portugal after the 1974 Revolution, when the country transited from dictatorship to democracy (Silva, 2019b).

The purpose here is not to produce an in-depth critical analysis of the narratives and the results attained, but to explore how the methodological framework based on oral history, biographic methods and a narrative analysis approach induced critical reflection, reflexivity and identity discourses in the subjects. Initially, the option of collecting oral histories was not thought to encourage critical reflections, much less reflexivity from the interviewed subjects. In fact, it was during interview collection and later when the accounts were being analysed, that it became clear informants were producing 
discourses that highlighted points of rupture in their biographies whilst signalling the socio-political circumstances that influenced their life options and biographic trajectory. Besides identifying those moments and reflecting about them, some interviewees produced elaborate discourses on how they reasoned and dealt with professional identity, not just regarding the past, but also manifesting their position in relation to present-day professional situation and their personal identification - and in some cases, deidentification - with the profession.

The next section will focus on clarifying the conceptual framework, elucidating the importance of the critical reflection-reflexivity nexus in social work research and practice, and shedding light on the relationship between the latter and biographic methods and oral history. Then, the research context and methodological framework on which this paper is based will be addressed, followed by three examples of critical reflection, reflexivity and identity framing taken from the empirical data set.

\section{From oral history and biographic methods to critical reflection and identity in social work research}

\section{Oral history and social work research}

Though relatively marginal to social work research, resorting to oral history sources goes back to the earliest days of the profession, when $19^{\text {th }}$ century social reformists like Charles Booth, Octavia Hill or Beatrice Webb used historical oral accounts in their surveys (Thompson, 2000). Oral history was present in social work historical research before the 1950s, when research methodology in this profession was far more pluralistic than one might consider (Fisher and Dybicz, 1999), but it declined to a point of near invisibility, though. The staggering influence of logical positivism on mainstream social work prompted a fixation with scientific validity and reliability, hindering the use of history approaches in general and in particular of oral history sources as far as social work research is considered (Guiraldelli, 2013). Oral history, in the context of the social sciences and history itself, fought against similar accusations and endured a battle to 
seek a recognition that was to be conquered only in the 1960s (Williams, 2018), as ethnomethodologies and microhistory developed.

Historical research within social work was revived in the 1980s and 1990s, partly driven by the narrative turn (Riessman, 2001a; Riessman and Quinney, 2005) and thanks to the emergence of a critical re-examining of the profession (Fisher and Dybicz, 1999) and the historical ties to the political contexts and world-systems which had been framing social work's trajectory throughout time (Lorenz, 1994, 2007).

Interestingly, from the 1990 s onwards, oral history has acquired space in social work as an instrument to support practice. Its relevance for social workers had already been implied by the sociologist and historian Thompson (2000), who signalled its instrumentality for therapeutic ends. From within the profession, the contribution of oral history to practice, namely in terms of intervention with older adults, traumatized patients or children, was explored by Martin $(1995,1999)$ who saw it as a means not only to counter the depersonalization often caused by psychodynamic methods but also to convey information about (and from) underrepresented groups. When using oral history in social work research, professionals are not just invited to speak about themselves. While doing it, they give voice to those who crossed their path of practice, bringing to the front-stage of research the singularities of people enduring harsh living conditions (Guiraldelli, 2013). For Martin (1995: 142), oral history was also fundamental to 'fill gaps in [the] historical literature' of the discipline and the profession. More recently, Williams (2018) showed how oral history can be used by social workers to produce and sustain participatory and empowering practices and De Wilde et al., (2020: 95) called the attention to the role oral history may have in questioning and critically deconstructing contemporary 'politics of apology'.

Grounded on a dialectic perspective, Guiraldelli (2013) counters the critics of oral history for its excessive focus on the micro-sociological level and its dependence on the contingencies of personal life facts. In his view, oral history allows thinking the profession 
critically and reflectively in its singularities and in connection with the universality and totality of complex social life. In that sense, oral history allows perceiving the particularities not just of social workers within their personal and professional lives, but also the interactions and powerplays they establish with the recipients of their intervention, their professional peers and other social actors, as well as with policy frameworks and socio-political and economic structures. With the support of biographic methods, oral history does more than granting access to individual past experiences, insofar as it positions 'speakers within networks of social and cultural expectations' (Hyvärinen, 2008: 457).

Oral history, biographic methods and critical reflection

The use of oral history in social work should not be seen as an end in itself, but rather as a means to understand complex social life and the relations professionals establish within that complexity. Relying on narrative processes, oral history becomes a powerful tool to unearth critical reflective accounts, as subjects reminisce over their interactions over time, appraising and reconstructing their pasts. Here, oral history becomes the vehicle of an interpretive enterprise undertaken and shared by both the subject and the researcher. While often prompting biographic narrations, oral history invites producing more than a mere account of facts; it offers an interpretation of life experiences (Hyvärinen, 2008).

Following this interpretive footpath, oral history and biographic methods take the researcher beyond the thresholds of descriptive inquiry, enabling us to see reality in a phenomenological perspective as biographic trajectories reveal the moments of crisis, the ruptures (Caetano, 2011) and the contexts of decision-making (whether instilling changes, or maintaining existing options). In the context of sociological and historical research of professions, social professions included, life histories collected through oral history grant the researcher access to the making of alternative professional projects and to the mediations and/or ruptures with the mainstream. This idea brings us closer to the 
notion that biographic narratives are particularly useful to reach not just stigmatised, marginalised and less empowered actors. As Thompson (2000) suggested and Schiettecat et al. (2018) have demonstrated in their study on mobilities in and out of poverty, life histories can also provide access to the accounts of other less visible and 'rarely heard narrators' (Shaw and Holland, 2014: 151), like in the case of this research, social workers.

The narratives generated through biographic inquiry are highly prone to produce critical reflection and reflexivity. Both have become key in social work research and practice (Fook and Gardner, 2007; Nygren and Blom, 2001; Shaw and Holland, 2014) especially after the 1980s, in the wake of post-modern and post-structural debates and, later, critical realism (Burack-Weiss, 2017; Healy, 2005; Houston, 2001; Longhofer and Floersch, 2012; Witkin, 2012). Here, the terms critical reflection and reflexivity are not to be used interchangeably. To differentiate both concepts, I rely on D'Cruz, Gillingham, and Melendez (2007) who, based on Schon's (1983) distinction between reflection-on-action and reflection-in-action, suggest critical reflection occurs when critical incidents are evoked by the subjects and knowledge is produced around that process of remembrance. Because the "critical incident is firmly in the past, and is represented as a learning opportunity for the future' (D'Cruz et al., 2007: 83), critical reflection diverges from reflexivity, insofar as the latter represents a critical form of knowledge production that is founded in close time proximity to the subject's experience, whilst the former sits in a broader time frame, i.e., more entrenched in the past. From this perspective, critical reflection can be understood as a process particularly suitable for bridging individual action and the socio-historical context.

Presenting critical reflection in these terms brings one to Archer's (2003) concept of reflexivity as a mediating mechanism between structure and agency. As such, the internal conversations produced by the individuals, when asked to narrate their biographies, become reflexive as subjects reveal mutual causal relations between 
structures and actors. This subjectification of personal and interpersonal experience offered by biographic narratives presents a window to observe identity formations (Dubar, 1998; Hall and White, 2005; Shaw and Holland, 2014).

Being reflexive means becoming able to critically reflect on actions and interactions and, based on that, to act in the world (D'Cruz et al., 2007). This can be attained through biographic narratives, as they have the power the produce (or induce) critical reflexion and reflexivity (Dubar, 2006). What I am referring to is a process of self-induced reconstitution of actions and interactions which allows the identification of biographic ruptures (Lahire, 2005, 2008). When doing so, subjects can do more than simply reappraising their deeds, they can instil changes in their future action, shaping and reshaping identity. However, not belittling the capacity biographic inquiry has to turn biographic narratives into reflexivity (Dubar, 2006), if one is to address reflexivity in its full extent, other than identifying critical episodes and incidents (D'Cruz et al., 2007), individuals' narratives should substantiate points of rupture in their biographies in a highly descriptive manner (Caetano, 2015) and produce propositional discourses and conceive possible lines of action (Archer, 2003).

\section{Using oral history to produce biographic and professional narratives: contextual and methodological frameworks}

As mentioned earlier, this article draws on an ongoing research on the participation of social workers in the process of transition from right-wing conservative dictatorship to constitutional democracy in the 1970 s in Portugal. It was a process launched by a military coup led by mid-rank officers on April $25^{\text {th }} 1974$, which overthrew the 48-year-old nationalist repressive regime. In the almost two years that followed the coup, a series of radical political, social and economic changes affected the country, leading to direct democracy practices, massive social reforms to recognise and protect labour and civil rights, the nationalisation of private economic assets and companies, not forgetting the independence of African and Asian territories under Portuguese colonial administration. 
This stage was to be called PREC, a Portuguese acronym for Revolutionary Process Under Way, a period which harboured a diversity of participatory social and political experiences and progressive programmes. It was also a time of political turmoil, civic unrest and vast collective mobilisation. This radicalisation, which brought Portugal to the brink of civil war, was stopped by a counter-revolutionary coup led by moderate army officers in November 1975, paving the way to what was to become Portugal's multi-party constitutional democracy. The aim of this research is to identify and interview social workers who willingly and actively participated in those Revolutionary programmes and contexts, collecting and analysing the memories they held from those experiences.

From 2016 to 2018, 14 in-depth semi-structured interviews were carried out with 13 women and one man. The interview guides were thought to be as flexible as possible to provide interviewees with the autonomy to report, describe and elaborate on issues they saw relevant. Though not initially conceived to prompt internal conversations (Archer, 2003), the interview guides included topics that somehow invited the subjects to elaborate on their current concerns and on how they understood the changes in the profession in particular and in society in general. The presence of such questions in certain points of the guides were, indeed, able to initiate the internal dialogues (Caetano, 2015), which turned the biographic inquiry into a critical reflective instrument. All interviews but two were collected in a single session, which lasted from two to five hours. Regarding the double session interviews, one took four hours total and the other 10 hours total.

Though critical reflections pervaded all the testimonies, it was the two subjects whose interviews occurred in two separate sessions (with a two-week interval between the first and the follow-up interview) who developed more critical and reflexive insights. Without disregarding each interviewee's idiosyncrasies, the result was highly influenced by their having been interviewed twice. On the second session, both subjects inadvertently started the interview on their own without being asked to, resuming topics and ideas they 
had been turning over in their minds after their first session. The second encounter allowed revisiting the issues, episodes and rationalisations which were invoked in the earlier meeting, producing not just a re-narration, but also a critical reasoning of previously told facts. A circumstance which should not to be regarded as strange because, as Frank (2012: 37) notes, concerning the dialogical nature of narrative analysis, 'people tell stories in order to revise their self-understanding, and any story stands to be revised in subsequent stories'. If the first interview prompted an encounter with the subjects' past, allowing more descriptive elements to emerge, the second one allowed a reflection about the facts, deeds and interactions of the past, thus adding more historicity to the process and leading to the identification of multiple points of rupture in the subjects' life trajectories, a condition closely tied to the production of reflective narratives, as mentioned by Dubar (2006). ${ }^{1}$

In terms of research, the data gathered during the interviews was analysed using two distinct methods. Initially, the transcribed material was subjected to categorial content analysis. On a second phase, those very same interviews underwent narrative analysis, which resulted in a more clear surfacing of critical reflection and identity. Fragmented by the coding process, the information allowed cross subject comparison and interesting analytic scrutiny, considering the topics of the discussion. However, dense critical reflection, reflexivity and identity (re)framing became evident once the subjects' discourse was analysed in continuum, as a 'whole' (Frank, 2012: 43). This was not a surprise, considering the limitations of inductive thematic coding when compared to narrative analysis (Riessman and Quinney, 2005). Here, I align with Hall and White's (2005) critique, placing coding analysis closer to an empiricist approach which tends to deviate the researchers' focus from the complexity of social life and from more dense interactional rapports.

\footnotetext{
${ }^{1}$ All the interviews were collected in places indicated by the subjects: eight were conducted in their homes, four in secluded spaces in their work places, and only two in public venues.
} 
The narrative analysis conducted in this research relied on reading the interview transcripts as a story, as an account where description, language and context of production, structural features of discourse, dialogical aspects and relation with other stories were taken into consideration, as Riessman and Quinney (2005) suggested (in turn, based on Elliot Mishler). My approach was also influenced by Frank's (2012) dialogue narrative analysis. Both Riessman and Frank take the stories produced by informants as plain objects of narrative analysis where the search for 'disruptive life events [and] accounts of "personal troubles" (Riessman, 2001b: 55) as well as 'complicating events' (and resolutions) (Frank, 2012: 42) become key. These disruptions very much resemble the already mentioned biographic crisis or ruptures present in life stories (Caetano, 2015; Lahire, 2008). Though drawing on Frank's (2012) dialogue narrative analysis, which suggests a somewhat less tightly systematized scheme, my analysis, in certain points, evidenced Labovian key-moments in the subjects' account, especially resolutions (Hyvärinen, 2008; Shaw and Holland, 2014).

As Riessman and Quinney (2005) note, writing articles whose results depend on dense qualitative information, often manifested through long thick narratives, is always a challenging task. When writing this article, that difficulty came up. Given the impracticality of presenting a thorough narrative analysis, three examples from the set of 14 interviewees will be used. In each case, moments of critical reflection and discourse on identity will be signalled, analysed and illustrated with excerpts taken from the transcripts.

\section{From narrative to critical reflection and identity (re)framing - exploring three examples}

\section{Example one}

The first example refers to a female interviewee, born in 1948 into a Lisbon's urban high bourgeois family, closely aligned with conservative right-wing values and supportive of the dictatorial establishment. When the interview took place, she was retired from an 
University academic position. The interview was recorded in a single session that lasted $1 \mathrm{hr}$ and $45 \mathrm{~min}$. Right in the beginning of the interview, in reaction to the first topic concerning her initial academic trajectory, she addressed the path that took her to social work:

[When enrolling in higher education] I applied, in that first year, to two places: philosophy and social work. Between becoming a philosophy teacher or changing the world, which was something we believed could be done through social work, I chose changing the world. Where did my politicisation come from?

The issue of the political dimension of the profession was highlighted, almost immediately, without being directly asked about it - note the question posed by the subject, suggesting a possible direction of the story into a foreseeable self-reflective account. A sense of naiveté transpires when remembering past options: it was 'something we believed' expresses, with candour, both the ingenuity and the idealism which commanded her decisions when she was younger. Note, also, the change from a first person to a collective voice when referring to idealistic views of the world. This sense of naiveté will appear again in the account and it will be important to understand the subjects' future options, biographic ruptures and professional (dis)identification, as we will be able to see later. That question marks an earlier point of reflection in this interviewee's life story and sets, from the start, the significance of identity in her account, especially regarding politically-related choices and political affiliation. One might argue that when she asks 'Where did my politicisation come from?', she is asking for something more than a where did it come from, she is inquiring how did I became such, as if the question implied an early allusion to personal identity and political self-identification.

Personal actions and life choices take on meaning when analysed in the framework of the subject's life trajectory, her contextual social milieu and her family relations. An evidence of such appeared in the first quarter of the interview: 
In my last [social work] internship, in a horrific shantytown, it was raining heavily and the priest allowed people to seek refuge inside the church. Then, I had the brilliant idea, with other two fellow colleagues, of making an exhibition outside of that rich church in that affluent neighbourhood: we held a photography display taken by the [poor] people - ahh... participation! In less than 24 hours, the PIDE [political police] went there. The priest was taken in for interrogation and the senior social worker considered terminating our internship because we didn't comply with professional deontology, though later she ended up defending us before the School's board. We were so naïve.

References to the inherent political mandate of the social work profession pervade this interviewee's account. When referring to the interactions she had established with her professional peers or publics, this subject, who graduated in social work in 1970, produced a narrative punctuated by critical reflections which reinforce her claims regarding what she considered social work should be about. As the interviewee, herself, set a dialogical dynamic with the researcher, those critical reflections around her days as social work student emerged in the midst of the conversation:

This is to show you that the profession and its politicisation or the issue of justice and inequality, they've always been tied to professional practice. However, we weren't conscious of that political dimension. By that time we were kind of silly, we had no idea.

The narrative becomes reflexive, exposing a paradoxical or divergent rapport between social condition and professional and life options. As the account develops, it shows the trajectory of a bourgeois social work student who defies traditional professional canons, seeking a commitment with the downtrodden through forms of intervention outside of conservative assistance charity, defying, also, her own patriarchal authority and relinquishing social status quo and financial security. For her, working as social worker in Portugal, then, was as an unlikely possibility:

There was a problem: in the meantime, I became a single mother... [silence]. Before the $25^{\text {th }}$ April [1974] how could a single mother get a job as a social worker, when social workers were there to show people models of virtue? 
Her option of leaving Portugal to study abroad, in 1970, can be read as another step towards the construction of her political self and disaffiliation from conservativism (social, professional, educational, familial):

Back then [late 1960s], I didn't separate the political from the professional. How did I acquire it [political conscience]? Because my education [social work degree] had been very flimsy. What interested me most was sociology and I ended up in Paris [1970] in the aftermath of May 68, where all the [Portuguese] refugees were, amongst some of the best professors of the time, Alain Touraine, Castells. [In 1971] I decided to move to the United States. The UCLA was highly politicised then. Angela Davis was there, the black power guys also. That was very violent.

The story easily turns into a biographic account of how political identity and action took form. Already graduated as a social worker, facing the enduring social and professional conservativism and unable to foresee changes in the short run, she sought other places to carry on her life and apprenticeship. Paris and Los Angeles, as elected destinations, represented sites of liberty, free thinking, vibrant intellectual discussion, academic advancement and venues of revolutionary action and thought. Living abroad for nearly four years was important to develop political conscience, critical thinking and to establish contact with political activists. When she returned to Portugal, before the 1974 Revolution, she joined the Revolutionary Brigades (RB), a subversive political organisation known for carrying out armed actions against the dictatorial establishment. Joining the RBs meant taking another step, a more radical one, towards change:

In Paris, the arguments we had were very intellectualoid. It was café talk, a bit dilettante. When I returned to Portugal, I got involved in the [Revolutionary] Brigades, until 74. I was there for about a year. We held political meetings to discuss how to get rid of the situation [dictatorship] and start throwing bombs to make a Revolution. There it is: we wanted to be more radical than the Communist Party brigades My adhesion [to the RBs] was political, meaning that 'It must end! It's not possible to continue living in this ignorance. This dark night must end. People must regain their freedom. We must retake democracy'. 
Integrating the RBs forced the subject to go into hiding and it was under that condition that she saw the $25^{\text {th }}$ April Revolution happen. Realising that the Revolution was indeed laying the ground for democracy, she disaffiliated from the RBs:

I can tell you that I didn't kill anyone, neither went shooting around, but that part I don't want to talk about. Anyhow, after the $25^{\text {th }}$ April, the RBs went nuts. I understood perfectly that the Revolution was a rupture with fascism and an attempt to implement a democratic society. There was no need to keep pursuing that radical way. I became more conservative in defence of democracy according to European standards.

The above mentioned passage showcases how reflexivity looms in the narrative, as the subject interprets her life experience. What sounded like a firm progression along a radical path is reframed as the subject assumes her ideological repositioning in the context of socio-political changes. The passage shows identity forming and reframing under changing circumstances and how it develops in the story: the rebellious naïve youth, the radical activist, the not so radical idealist.

The 1974 Revolution brings the subject back to the social work profession and to one of the forefronts of the revolutionary process, the SAAL programme. The SAAL (Local Ambulatory Backup Service) was an innovative housing programme led by the national Housing Development Fund, active between July 1974 and October 1976. Among its objectives was the implementation of unconventional solutions regarding housing construction and rehabilitation, relying on participatory processes and wide involvement of local collective structures (Andrade, 1992). Part of the programme implied setting community organisation strategies to which social workers gave a major contribution (Silva, 2018, 2019a). Referring to this period, the subject's narrative reveals the presence of decisions that do not coincide and, in certain moments, collide with dominant social work professional identity discourses:

As people were about to be evicted I went immediately to that neighbourhood and said: 'What if we organise an association and start a self-organised construction process?'. 


\begin{abstract}
Afterwards, I worked in the creation of social facilities: we've created a kindergarten, a sports group, those things a community social worker does. My colleagues said: 'Everybody must do intake and casework. And I replied: 'Yes, indeed. If everyone does community intervention'. So, my stand was: 'While everybody isn't doing community intervention, I won't do casework'. Community work meant working beyond normal work hours and on weekends, while staying put, waiting for people to come over, was more comfortable.
\end{abstract}

After 1976, as she perceived that her ideal of professional practice (which was, in her own words, promoting change and making communities grow) no longer had the contextual political conditions to be held, she retired from direct practice, and disaffiliated herself, as a professional, from social work.

The narrative shows that the politically driven and community-immersed type of practice was a basic condition of her professional commitment and a key axiological element of her identity as a social worker. The demise of the Revolutionary project, which occurred after 1976, is connected to a moment of life crisis which led to a detachment from the profession. The subject's account identifies points of structural socio-political change, signalling corresponding moments of rupture with the profession:

My greatest accomplishment as a social worker: I've never given a subsidy to the poor. [After] that involvement in the Revolutionary Process, no job would satisfy us. So, I entered [a Public University], and had no regrets about leaving the Social Security, because nothing was done there anymore. It was no longer possible. We were forbidden to speak with the [community] services. That was the complete destruction of our work principles. So, I changed careers.

Rather than justifying parting from the profession as a consequence of a mere personal option, the narrative shows her choice was influenced by the changes that were affecting the profession in terms of service organisation and intervention profiles. Changes which clashed with her ideal professional cut. Her identification as a social worker found no match in the kind of services, practices and institutional design that followed the post- 
Revolutionary era - 'So, I changed careers' appears as the closing remark, the resolution to the story.

\section{Example two}

At the beginning of the interview, this social worker, born in 1955 into a working-class family from Lisbon's industrial periphery, flashed back to her childhood and early school days. At the time of the interview, she held a position in a public library in Lisbon, being in charge of educational and occupational activities. In the initial part of the narrative, collected in a $2 \mathrm{hr}$ and $30 \mathrm{mn}$ interview, visiting the past meant more than a simple diachronic contextualization of her social and family background. The account, while reminiscing on earlier biographic circumstances and facts in the manner of an internal conversation (Archer, 2003), provides crucial information to the understanding of the subjects' life options and ruptures as well as her peculiar professional trajectory and (de)identification. It was as if those earliest moments of interview could work as a Rosetta stone, allowing to decode and comprehend the various moments and actions in life:

In my first year at school the teacher called my mother in to say that I might be somewhat retarded. On the second year, I was already a good student, but I didn't like school. I just wanted to go to work. When I finished the fourth grade, I became a good student, though wishing all the time to drop out of school and get a job. My grades were excellent and I already knew that I wanted to work in something related to the social.

Unlike most of the social workers who were interviewed, her narrative does not present clear points of rupture or situations of evident crisis; instead, it frames a continuity in which biographic and professional trajectories (dimensions which cannot be separated) hold an intrinsic coherence and a structured orientation. The following quote offers a perspective of how that continuity is voiced in the narrative:

I was so lucky, because in my first year in the social work degree [1972] I had professors who had been educated in France during the May 68 period. It was at [Lisbon's Higher] Institute [of Social Work] that I found myself. Back then, the Institute was an oasis in the 
desert, filled with very active people. I went [1972-1973] to a few social workers' Union meetings and it was there that I really started to understand the country I was living in. My militancy at the [social work] school made me participate in everything, in all the meetings, in all the assemblies. I was involved. My first internship happened in 1974, right after the $25^{\text {th }}$ April [Revolution], in Trás-os-Montes [the mountainous rural northeasternmost part of the country]. There, we worked in the fields, which was harsh, and I also did adult-education with women. That experience struck me a lot. In my third year, my internship was in a neighbourhood in Lisbon, in the SAAL. That was an option. Wanting to work in housing was probably influenced by my own childhood experience in the [working class] neighbourhoods [in the outskirts of Lisbon]. My radicalism was about that: I thought that I would learn from the people and I didn't want to be paid for it. Ultimately, I went and lived in that neighbourhood until 1990 [where she developed her internship practice in a SAAL project]. My option was to live in the neighbourhood as a fully entitled member [of the community].

When points of rupture and crisis seem to occur in the narrative, they do not present as situations of deadlock in which the subject finds herself facing hard-to-solve dilemmas. In turn, those situations are depicted in the narrative as natural life stages when the subject takes somewhat likely decisions, confirming and reaffirming the subject's will in obedience to a well determined ethical and political canon. This is representative of the narration's reflexive feature. The narrator moves beyond simply describing her actions and informing her decisions, revealing mutual causal relations between structural circumstances and her own actions.

As referred earlier in this article, in social work, biographic narratives collected through oral history allow researchers to access the making of alternative professional projects, leading, necessarily, to grasp identity related issues. In this case, the narrative provides clues that become useful to understand the radical construction of this subject's refractory professional identity: 
[When working in a SAAL project] I used my social work education, which I have never renounced. There, I did adult education work [using the Paulo Freire method] and participated in the managing and dynamisation of the residents' commissions and associations. My life experience led me to not wanting to become a social work professional. I didn't want to be a social work technician. I wanted to use the education and the knowledge provided by social work to be a person.

The subject's identification as a social worker is never at stake throughout her discourse; yet, she refuses to abide by or affiliate with mainstream social work. Rather than assuming an institutional position as a front-line practitioner or becoming a bureaucratic professional, she manifests a recurrent preference to work in adult education processes and in close articulation with grassroots movements. As the narration continues, frequent critical reflections situating herself in relation to mainstream professional profiles appear. These critical reflections are often enfolded in identity statements, where the professional 'I' is hardly separated from the personal self:

And there's always that issue about the professional model and professional profile and today I still think about it in these terms: it is so hard being a human being, that I no longer worry about being a professional.

Across her narrative, decision making constantly points in the opposite direction to what one would expect: the good elementary school student who favoured switching from education to work; the high-achieving high school student, qualified to be enrolled in a financially more rewarding degree, but who preferred to study social work instead; a politically active social work student, with a good academic performance, who chose to take a diverging professional path, resisting to incorporate a collective identity that was being forged around the values of professionalism. It is worth noting that, in the late 1990s, when applying to a public job, she refused being hired as a Social Work Higher Technician. Then, the designation of the social work career in public services (Branco, 2009) which evokes a professional identity related to positivist, rational and scientificbureaucratic principles (Amaro, 2015). The interviewee's final statement, which can be 
read as a form of resolution to the story, renders the refusal of professionalism particularly evident:

Never wanted, never was [a social work professional]. I've always thought that there was a place for a less standardized model of intervention, in line with Latin-American social work. [When] I walked away [from the profession], I told myself: 'No, I don't want to be a social work professional'. Though, deep down, I ended up being that. And I'm perfectly aware of the contradiction.

\section{Example three}

This example is taken from the statements (recorded in two sessions) provided by the youngest of the interviewees, born in 1955 into an urban middle-class family from Lisbon. At the time of the interview, she was a social worker in a Social Security branch. Having entered Lisbon's Higher Institute of Social Work in September 1974, she soon caught up with the revolutionary flow and, following the radical changes introduced in social work's academic curricula and internship practice, she developed field observation assignments in rural cooperative movements, becoming a full member of one of the flagship initiatives of the revolutionary times, the Torre Bela agrarian cooperative. This cooperative, situated only $70 \mathrm{kms}$ away from Lisbon, was founded in April 1975 by a grassroots movement which occupied the hunting estate of an aristocratic family (Silva, 2019a).

The subject's narrative reports the frenzy of the revolutionary period and how it affected her perception of the profession and the inner crises she endured, especially those related to the ambiguities around professional representations. The next passage is expressive of such and the note on reconciliation can be read as an example of emerging reflexivity:

When I was doing my internship [1975], social work in institutional settings was highly questioned. The intervention done in the institutions was discredited and there was this hyper-valorisation of social movements and grassroots organisations; there was an 
alliance and an immersion in those movements without which social work was inconceivable, to the point of... it took me a lot to reconcile to social work.

The social work internship in the Cooperative during the revolutionary process did not promote a strong professional identity, on the contrary. As the narrative unfolds, in a reflective manner through a sequence of internal dialogues, all those identity issues and crisis, it also entails the subject's own interpretation of the causal relations between revolutionary immersion and professional disaffiliation:

The immersion [in the Torre Bela cooperative] was so intense that we almost forgot we were doing an internship. For a long time, I thought that it wasn't possible to exercise the profession from the outside [of grassroots movements]. So, in order to be the an ally of change, I needed to be inside. I had to partake from the inside. I had to live within. And that was a hard-to-solve inner conflict. I asked myself: how can I be a social worker while participating in a movement such as this, participating in processes of change from the base? Because the legitimacy of the intervention comes from the 'I, being part of', 'I, being there', 'I, being an ally'. If the movement doesn't take me as a social worker, what am I?

The internal dialogues produced during narrations are too obvious to go unnoticed in the analysis. They evidence the uncertainties, the doubts, the hesitations, instead of sound convictions and solid beliefs. Thus, the narrative develops over identity and around the qualms and possibilities that might contribute to frame it - 'For a long time, I thought that it wasn't possible'; 'What am I?'.

In 1976, the ending of the revolutionary process nearly made her giving up the social work degree:

Back then, [1974-1975], my reflection made me question social work as a profession. I finished my degree in 78 and, the first time I was hired as a social worker, it was in 87. We questioned the exercise of the profession because, especially I, thought that it had to be done through active and militant participation in transformative processes. Besides that, I don't know exactly for how long, I reflected over it was worth exercising a profession 
aimed at producing social changes without participating in the processes. It was nearly questioning the profession itself.

In fact, after 1978, right after graduating, she abandoned the profession (in her own expression) and went to work in Mozambique and, later, in the early 1980s, in southern Portugal, supporting rural cooperatives and agrarian projects. In the late 1980s, she assumed an institutional professional position in the Social Security, the State's general welfare service structure. The narrative stressed the biographic discontinuities and the seemingly paradoxical situations and life decisions. Returning to statutory social work can be read as a crucial rupture in a long developing process of estrangement from the profession:

I stepped away and it took me years to re-join social work. But, when I returned, I didn't do casework. I worked [in a local Health Centre unit] in school health programs. I entered the Social Security [in 1988] to occupy a position of Social Work Higher Technician - huh? - what to say about this?

Entering statutory social work influenced her decision to take a master's degree in social work and to become a social work teacher and that, in her own words, have proven to be two fundamental steps to reconcile herself to the profession. The way the narrative exposes the subject's coming back to the profession shows, again, the emerging of reflexivity as she re-interprets and re-signifies her past experience. Here, the subject does more than simply identifying a moment of reconciliation, she suggests that, firstly, reconciling is produced by a rationalisation happening in the very moment the narrative is being told and, secondly, that that rationalisation has the effect of validating a life trajectory and the choices made in the past:

[If] we're talking about rights' enactment, I think that my whole trajectory was one of a social worker. I'm thinking about that now... a reconciliation... I'm not sure if that's the right term, but reconciling is, somehow, validating all that path, which was not necessarily external to social work. I've always understood my job as a [process of] involvement. In several moments I've been able to do that sort of professional militancy. 
As in the previous example, right at the beginning, this interviewee's narrative provides pieces of information and a reflection that show how her dispositions were constructed and how they influenced the subject's relation with the professional practices that were to become mainstream after the revolutionary period. Carrying out assignments in cooperative projects and becoming a member of one was important to outline her perception of social work in more critical and radical terms and to disengage herself from more traditional, conservative and individualised concepts of professional practice. According to her, countering the constraints imposed by highly regulated institutional professional settings implied a stand of 'professional militancy', which meant being more actively involved with the publics when implementing programs and social measures. Identifying as professional militant, readdressed and reaffirmed how she reconciled herself to the profession, offering another example of how biographic interviewing prompts processes of reflexivity and identity formation.

\section{Ending remarks}

The use of biographic methods associated with oral history and supported by narrative analysis is not just a way of looking back at the past. It also allows researchers to perceive and understand the subjects' identification with the profession over the years until the present-day. Instead of conveying passive reports of individual life trajectories, this biographic approach invites the subjects to actively reflect on their life accomplishments and biographic options, allowing richer reflexive accounts.

The three examples presented in this article reveal how a methodological framework based on oral history, biographic methods and narrative analysis can contribute to induce the reflexive capacities owned by subjects, especially in view of their ability to develop critical reflections on their life trajectories.

The analysis of the narratives showed that, other than simply producing static accounts of past experiences, the use of biographic inquiry allows interviewees to re-capture, re- 
interpret and re-signify their own experiences while producing and reframing identity discourses in light of changing socio-political contexts.

Identity frameworks come out of oral history and biographic inquiry as people are invited to evaluate, as Thompson (2000: 157) puts it, their life trajectories, deeds and interactions. That process was particularly evident in the analysis of the interviewees' narratives. Though not having been directly asked to develop any kind of life balance, the subjects elaborated discourses that generated a critical examination of their attitudes, their decisions and both influenced professional identification.

Despite a large body of work on processes of critical reflection and reflexivity in social work, diachronic approaches based on the social and professional memory of social workers, collected through biographic inquiry, are rarer. I hope, with the present article, to have contributed to expand social work's historical critical research, by offering a look into a methodology which merges oral history, the biographic method and narrative analysis.

\section{Funding}

This work is supported by national funds, through the FCT - Portuguese Foundation for Science and Technology under the project UID/SOC/04011/2019.

\section{References}

Amaro MI (2015) Urgências e Emergências do Serviço Social - fundamentos da profissão na contemporaneidade. Lisboa: Universidade Católica Editora.

Andrade M (1992) O Estado, a Sociedade e a Questão da Habitação em Portugal --1960--1976. Pontifícia Universidade Católica de São Paulo \& Instituto Superior de Serviço Social de Lisboa.

Archer M (2003) Structure, Agency and the Internal Conversation. Cambridge: 
Cambridge University Press.

Branco F (2009) A Profissão de Assistente Social em Portugal. Locus Social 3: 61-89. Available from: http://www.locussocial.cesss-ucp.com.pt/page7/files/artigo-007cpaper-branco_Is00233.pdf.

Burack-Weiss A (2017) Introduction - Many ways of knowing. In: Burack-Weiss A (ed.), Narrative in Social Work practice: The power and possibility of story, New York: Columbia University Press, pp. 1-11.

Caetano A (2011) Para uma análise sociológica da reflexividade individual. Sociologia, Problemas e Praticas 66: 157-174.

Caetano A (2015) Personal reflexivity and biography: methodological challenges and strategies. International Journal of Social Research Methodology, Routledge 18(2): 227-242. Available from: http://dx.doi.org/10.1080/13645579.2014.885154.

D'Cruz H, Gillingham P and Melendez S (2007) Reflexivity, its meanings and relevance for social work: A critical review of the literature. British Journal of Social Work 37(1): 73-90.

De Wilde L, Vanobbergen B and Roets G (2020) The role of life histories in an age of apology: A presence of the past? Qualitative Social Work 19(1): 93-107.

Dubar C (1998) Usages sociaux et sociologiques de la notion d'identité. Recherche Sociale (147): 7-15.

Dubar C (2006) A Crise das Identidades: A interpretação de uma mutação. Porto: Afrontamento.

Fisher R and Dybicz P (1999) The Place of Historical Research in Social Work. Journal of Sociology \& Social Welfare 26(3): 105-124.

Fook J and Gardner F (2007) Practising Critical Reflection. Berkshire: Open University Press. 
Frank AW (2012) Practicing Dialogical Narrative Analysis. In: Holstein JA and Gubrium JF (eds), Varieties of Narrative Analysis, Los Angeles: Sage, pp. 33-52.

Guiraldelli R (2013) O enfoque metodológico da história oral na pesquisa em Serviço Social. Emancipação 13: 121-131.

Hall C and White S (2005) Looking Inside Professional Practice: Discourse, Narrative and Ethnographic Approaches to Social Work and Counselling. Qualitative Social Work 4(4): 379-390.

Healy K (2005) Social Work Theories in Context - Creating Frameworks for Practice. New York: Palgrave Macmillan.

Houston S (2001) Beyond Social Constructionism: Critical Realism and Social Work. The British Journal of Social Work 31(6): 845-861. Available from: http://www.jstor.org/stable/23716466\%5Cnhttp://www.jstor.org.proxy.uchicago.ed u/stable/pdfplus/10.2307/23716466.pdf?acceptTC=true.

Hyvärinen M (2008) Analyzing narratives and Story-Telling. In: Alasuutar P, Bickman L, and Brannen J (eds), The SAGE Handbook of Social Research Methods, London: Sage, pp. 447-460.

Lahire B (2005) Patrimónios individuais de disposições. Sociologia, Problemas e Práticas (49): 11-42.

Lahire B (2008) De la réflexivité dans la vie quotidienne: journal personnel, autobiographie et autres écritures de soi. Sociologie et sociétés 40(2): 165-179. Available from: http://id.erudit.org/iderudit/000652ar.

Longhofer $\mathrm{J}$ and Floersch J (2012) The Coming Crisis in Social Work: Some Thoughts on Social Work and Science. Research on Social Work Practice 22(5): 499-519. Lorenz W (1994) Social Work in a Changing Europe. London: Routledge. Lorenz W (2007) Practising history Memory and contemporary professional practice. 
International Social Work 50(5): 597-612.

Martin RR (1995) Oral History in Social Work: Rsearch, Assessment, and Intervention.

Martin RR (1999) Histories in Social Work. In: Shaw I and Lishman J (eds), Evaluation and Social Work practice, London: Sage, pp. 133-147.

Nygren L and Blom B (2001) Analysis of short reflective narratives: a method for the study of knowledge in social workers' actions. Qualitative Research 1(3): 369_ 384.

Riessman CK (2001a) Analysis of personal narratives. In: Gubrium JF and Holstein JA (eds), Handbook of interview research: Context \& method, Thousand Oaks: Sage, pp. 695-710.

Riessman CK (2001b) Personal troubles as social issues: A narrative of infertility in context. In: Shaw I and Gould N (eds), Qualitative Research in Social Work, London: Sage, pp. 55-61.

Riessman CK and Quinney L (2005) Narrative in Social Work - a Critical Review. Qualitative Social Work 4(4): 391-412.

Schiettecat T, Roets G and Vandenbroeck M (2018) Capturing life histories about movements into and out of poverty: A road with pits and bumps. Qualitative Social Work 17(3): 387-404.

Schon D (1983) The Reflective Practitionar. New York: Routledge.

Shaw I and Holland S (2014) Telling stories. In: Shaw I and Holland S (eds), Doing Qualitative Research in Social Work, London: Sage, pp. 147-164.

Silva PG (2018) Social workers in the Revolution: Social work's political agency and intervention in the Portuguese democratic transition (1974-1976). International Social Work 61(3): 425-436.

Silva PG (2019a) Radical Experiences of Portuguese Social Workers in the Vanguard 
of the 1974 Revolution. Journal of Progressive Human Services 30(3): 1-21.

Silva PG (2019b) The radical turn of Portuguese social work during the democratic transition (1974-76). Critical and Radical Social Work 7(1): 7-23.

Thompson P (2000) The Voice of the Past: Oral History. 3rd ed. Oxford: Oxford University Press.

Williams CC (2018) Critical oral history : Reflections on method and medium.

Qualitative Social Work Online Fir: 1-13.

Witkin SL (2012) An introduction to social constructionism. In: Witkin SL (ed.), Social Constructionism and Social Work Practice, New York: Columbia University Press, pp. 13-36. 